専門医症例報告

欠損部歯槽形態の変化を考慮した前歯部ブリッジ補綴の 1 症例

一瀬 昭太

\title{
A Case of Determining Bridge Shape for Patient with Anterior Tooth Loss and Evolving Gum Level
}

\author{
Shota Ichinose
}

\begin{abstract}
抄 録
症例の概要：患者は 71 歳女性。前歯部審美障害と咀嚼障害を主訴に来院した。下顎遊離端義歯床内面の

不適合からリライニングによる咬合支持の回復と，審美性を考慮したオベイドポンティックを利用した前 歯部陶材焼付鋳造冠ブリッジにより補綴処置を試みた症例である.

考察：オベイドポンティック形態を用いることで歯槽骨の吸収防止，歯肉縁形態，歯間乳頭の維持を考慮 した前歯部補綴処置が可能なことがわかった。

結論：前歯部審美障害を訴える患者に対してオベイドポンティックを選択した固定性補綴装置を用いるこ とは有効である。
\end{abstract}

和文キーワード

咬合支持，リライニング，オベイドポンティック

\section{ABSTRACT}

Patient: The patient was a 71-year-old female who visited our dental office. Her chief complaint was that of dissatisfaction with her anterior dental esthetics. Predictable prosthetic treatment with occlusal reconstruction was performed using a relined removable denture. Final restoration was made with a fixed ceramic bridge and ovate pontic for esthetic recovery.

Discussion: A fixed bridge with an ovate pontic could avoid alveolar bone disruption and also maintain the papilla shape as well as the gum level appropriately.

Conclusion: A fixed bridge with ovate pontic was deemed an appropriate treatment for the patient who was previously complaining about anterior dental esthetics.

\section{Key words}

occlusal support, relining, ovate pontic

\section{I. 緒 言}

近年，前歯部補綴修復に関する患者の審美的要求が高
まっている. 今回，前歯部歯根破折に伴う固定性ブリッ ジに関して歯槽部の形態の変化に考慮した 1 例を経験 したので報告する。

西関東支部（医療法人 審美会 鶴見歯科医院）

Nishi-Kanto Branch (Tsurumi Dental Clinic)

受付 : 2010 年 5 月 20 日/受理 : 2010 年 11 月 29 日

Received on May 20, 2010/Accepted on November 29, 2010 


\section{II. 症例の概要}

患者: 71 歳, 女性.

初診: 平成 18 年 1 月.

主訴 : 前歯部審美障害.

現病歴：約 10 年前に他院にて装着した 1 の陶材焼付 鋳造冠が昨日食事中に築造体と共に脱離した．同部は数 年前より脱離と再装着を繰り返していたとのことであ り，脱離した補綴装置の口蓋側金属面には，下顎前歯の 強い突き上げが原因と考えられるシャイニングスポット がみられた。

既往歴：特記事項なし.

現症：Ц1 は，歯肉縁下に及ぶ歯根破折を生じており， 自発痛はなかったが, 唇側中央部の MGJ 付近に膿瘍形 成および排膿が認められ，同部への圧痛があった (図 1). パノラマX線において, 全顎的に水平的骨吸収像が認 められ，上顎大兒歯部には一部垂直的骨吸収像が見受け られた。 また，下顎左側大拍歯部に残根と思われる不透 過像が認められた（図 2, 表 1)。両側顎関節部の変形 などはなく, 下顎頭の形態は左右対称であり, 関節窩と の位置関係も左右に差はなく, 顎関節の機能障害は疑わ れなかった。

初診時の咬合状態は, 前方運動時はアンテリアガイダ ンスが確立されており，側方運動時は，右側では犬歯お よび第一小臼歯, 左側では犬歯, 第一および第二小臼歯 によるグループファンクションドオクルージョンが確立 されていた。また前方, 側方運動時臼歯部に咬合干渉は なく, 左右下顎頭部の触診, 切歯点の開閉口経路が直線 的であることから，下顎頭の滑走運動もスムーズであっ たことを確認した。一方, 下顎臼歯部には可撤性部分床 義歯が装着されていたが，粘膜面の適合試験では均一な 適合が得られておらず，また，ピッチングを起こしてい ることを確認した。

そこで, 臼歯部の可撤性部分床義歯のリライニングに よる咬合支持の回復と, 審美性を考慮したオベイドポン ティックを利用した前歯部陶材焼付鋳造冠ブリッジによ り, 補綴処置を試みた。

\section{III. 治療内容と経過}

リライニングを含む義歯調整による臼歯部咬合支持を 回復したうえで，治療法について説明し同意が得られた ので歯根破折した 1 の抜歯を行い, 両隣接歯を支台歯 形成し, プロビジョナルレストレーションを装着した(図 3). 特に, 抜歯した 1 は，主訴の審美性を考慮して,

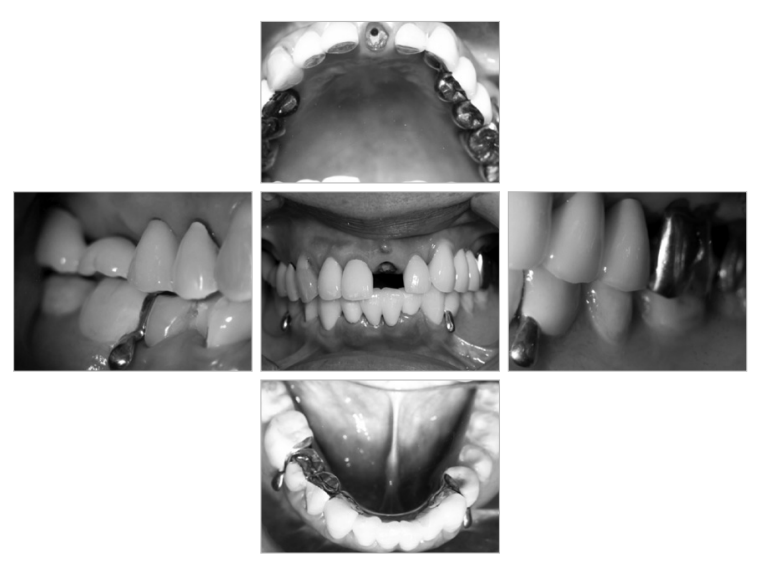

図 1 Intraoral photography at first examination 初診時口腔内写真

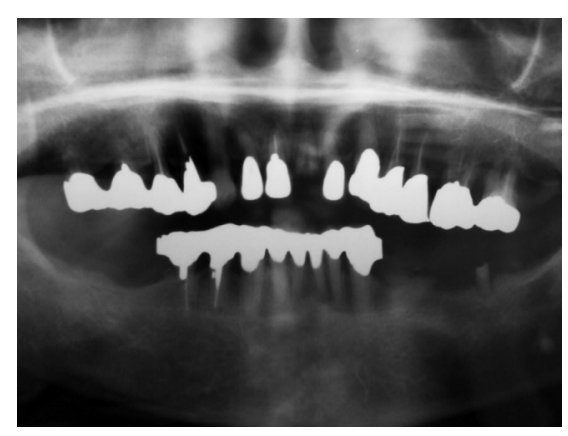

図 2 Orthopantomograph at first examination 初診時パノラマX $\mathrm{X}$ 線写真

表 1 Periodontal conditions at first examination 初診時歯周精密検査.

\begin{tabular}{|c|c|c|c|c|c|c|c|c|c|c|c|c|c|c|c|c|c|c|}
\hline \multirow{2}{*}{\multicolumn{2}{|c|}{$\begin{array}{l}\text { Furcation } \\
\text { Mobility }\end{array}$}} & $Y$ & $Y$ & $Y$ & & & & & & & & & & \multirow[b]{2}{*}{1} & & \multicolumn{2}{|c|}{ YY } & \multirow[t]{2}{*}{$Y$} \\
\hline & & & 1 & 1 & & 1 & 1 & 1 & 2 & 2 & 2 & 2 & 1 & & & 1 & 1 & \\
\hline \multirow{3}{*}{\multicolumn{2}{|c|}{\begin{tabular}{l|l}
$\begin{array}{l}\text { Probing } \\
\text { Depth }\end{array}$ \\
\end{tabular}}} & & $4 \sqrt[33]{3}$ & 33 & & \begin{tabular}{|l|l|l|}
2 & 3 & 3 \\
\end{tabular} & \begin{tabular}{l|l|l|l}
3 & 2 & 3 &
\end{tabular} & \begin{tabular}{|l|l|l|}
3 & 2 & 3 \\
\end{tabular} & 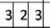 & $\begin{array}{l}3233 \\
\end{array}$ & $\begin{array}{l}34 \\
433 \\
\end{array}$ & \begin{tabular}{l|l|l}
3 & 2 & 3 \\
\end{tabular} & \begin{tabular}{l|l|l}
3 & 2 & 3 \\
\end{tabular} & \begin{tabular}{|l|l|l|l|}
3 & 2 & 3 \\
\end{tabular} & \begin{tabular}{|l|l|l|} 
& 2 & 3 \\
\end{tabular} & \begin{tabular}{ll|l|l|l|l|}
3 & 2 &
\end{tabular} & 524 & \\
\hline & $\mathrm{L}$ & & 423 & \begin{tabular}{|l|l|}
3 & 3 \\
\end{tabular} & & \begin{tabular}{|l|l|}
2 & 3 \\
\end{tabular} & $3 \sqrt{233}$ & \begin{tabular}{|l|l|l|}
3 & 2 & 3 \\
\end{tabular} & \begin{tabular}{|l|l|}
23 & 33 \\
\end{tabular} & $\begin{array}{l}32333 \\
\end{array}$ & $\begin{array}{l}3233 \\
\end{array}$ & $\begin{array}{ll}32 & 333 \\
\end{array}$ & \begin{tabular}{l|l|l|}
3 & 3 & 3
\end{tabular} & \begin{tabular}{|l|l|l|l|}
3 & 2 & 3 \\
\end{tabular} & \begin{tabular}{|l|l|l|}
3 & 2 & 3 \\
\end{tabular} & \begin{tabular}{|l|l|l|}
3 & 23 \\
\end{tabular} & 423 & \\
\hline & & 8 & 7 & 6 & & 5 & 4 & 3 & 2 & 1 & 1 & 2 & 3 & 4 & & 6 & 7 & 8 \\
\hline \multirow{2}{*}{\begin{tabular}{l|l} 
Probing \\
Depth
\end{tabular}} & & & & & & \begin{tabular}{|l|l|l|}
3 & 3 & 3 \\
\end{tabular} & \begin{tabular}{l|l}
32 & 33
\end{tabular} & \begin{tabular}{l|l|l|}
3 & 2 & 3 \\
\end{tabular} & 323 & $\begin{array}{l}3233 \\
\end{array}$ & \begin{tabular}{l|l|l}
32 & 33 \\
\end{tabular} & \begin{tabular}{l|l|l|}
3 & 2 & 3 \\
\end{tabular} & \begin{tabular}{|l|l|l|}
3 & 2 & 3 \\
\end{tabular} & & & & & \\
\hline & $\mathrm{B}$ & & & & & 233 & 3233 & $\begin{array}{lll}3 & 2 & 3 \\
\end{array}$ & 323 & 3233 & \begin{tabular}{l|l|l}
3 & 2 & 3 \\
\end{tabular} & \begin{tabular}{l|l|l|l|l|l|l|l|} 
& 2 & 3
\end{tabular} & \begin{tabular}{|l|l|l|}
3 & 2 & 3 \\
\end{tabular} & & & & & \\
\hline Mobility & & & & & & 1 & 1 & 1 & 1 & 1 & 1 & 1 & 1 & & & & & \\
\hline Furcation & & & & & & & & & & & & & & & & & & \\
\hline
\end{tabular}

オベイトポンティックを用いてポンティック形態の調整 を行いながら, 欠損部歯槽底粘膜の形態修正を行った。 歯肉の安定を確認後, 支台歯形成, 印象採得を行い陶材 焼付鋳造冠ブリッジを装着する計画とした。 また，同時 に，口腔清掃指導および，スケーリング，ルートプレー ニングを行い, 残存歯の歯周治療による改善を立案した。 初診時は, 応急処置として脱離した 1 にテンポラリ ークラウンを仮装着した。 その後, 咬合支持の回復とし て沈下のみられた下顎義歯に対し, 残根部の抜歯窩の治 癒をみながら, アタッチメント下部をユーティリティー ワックスでブロックアウトし，咬合圧下にて床下粘膜部 をシリコン印象材にて印象採得後, 咬合器に付着して, 

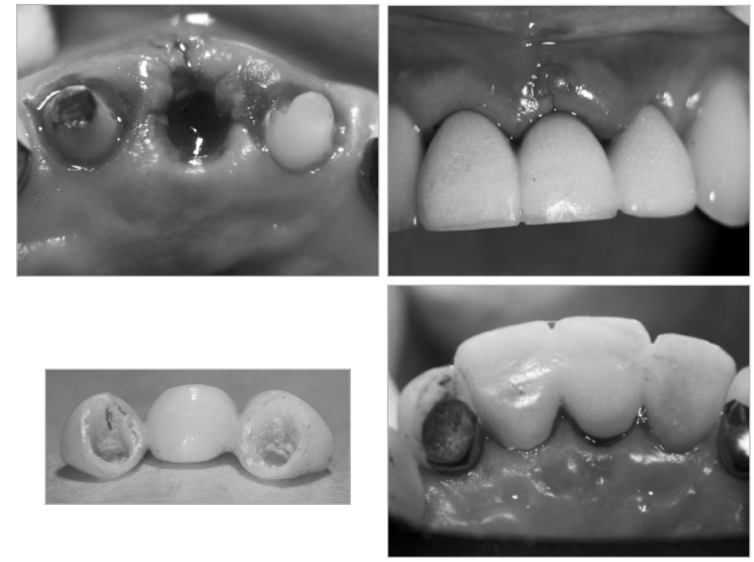

図 $3\lfloor 1$ extraction, (1) 1 (2) insertion of provisional restoration

〔1 抜歯, (1)|1 (2) プロビジョナルレストレーション装着
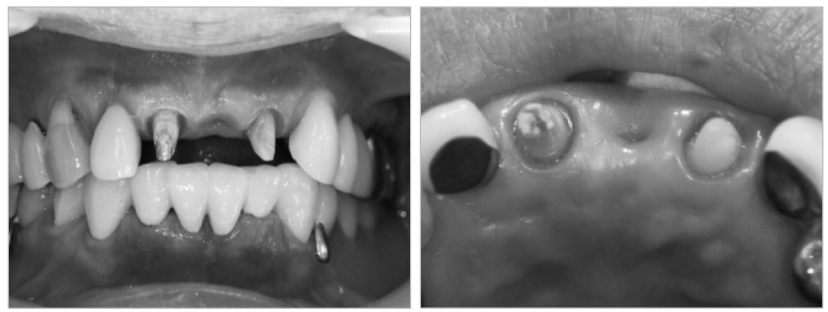

図 4 Tooth preparation 支台歯形成

間接法によるリライニングを行った。

支台歯形成については，Tarnow らがコンタクトポ イントから歯槽骨頂までの距離が $5 \mathrm{~mm}$ 以下であれば, ほぼ 100\%ブラックトライアングルが消失することを報

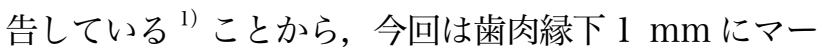
ジンを設定し歯槽骨頂部からコンタクトポイントが 5 $\mathrm{mm}$ になるように設定した。 また, 抜歯直後の歯槽骨 形態は，唇・舌側歯槽骨が裂開状に欠損することなく保 存された状態であった。そのため, プロビジョナルレス トレーションのポンティック部分は, 唇舌側の歯槽骨を 圧迫しないように，抜歯窩中央部にオベイドポンテイッ ク形態となるように加圧適合させた。唇側歯肉歯間乳頭 部は加圧しないよう, 適合させ装着した. プロビジョナ ルレストレーションのアンテリアガイダンスは咬合診査 により, 既存の誘導に問題がないと判断した。 そこで, フェイスボートランスファー後, 上下作業用模型を半調 節性咬合器に装着し, 前方チェックバイトにより得られ た矢状顆路角右側 $45^{\circ}$, 左側 $46^{\circ}$ を半調節性咬合器に設 定し， 1]，适の舌面誘導路に切歯路角を一致させ，ワッ クスアップを行い, レジンに重合後，口腔内で調整，装 着した。 ポンティック基底面の加圧の程度は，小濱らの

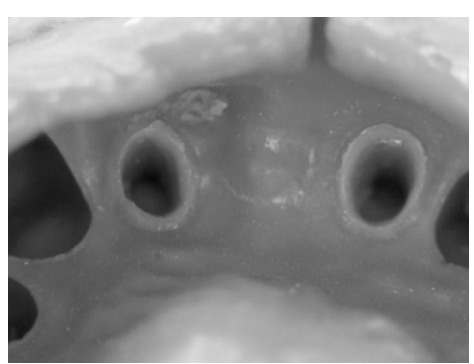

図 5 Final impression 印象採得
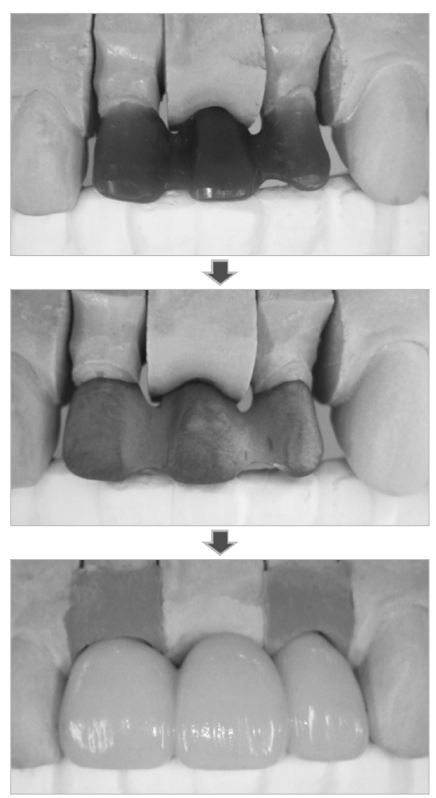

図 6 Making of final restoration ブリッジ製作過程

術式を参考にして，仮着後 10 分ほど観察し，貧血帯が

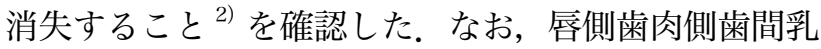
頭側は，加圧はせず適合するようにした。

抜歯から約 5 カ月後，ポンテイック基底面は約 $2 \mathrm{~mm}$ 程度唇側歯肉より歯槽頂部が陥凹した形態となり，歯間 乳頭部の歯肉の形態も審美的に満足でき，スキャロップ 形態も左右対称になった。清掃性にも問題がなく, ポン ティック底部粘膜面に炎症を生じていないことを確認し た (図 4)。

最終補綴装置は陶材燒付鋳造冠ブリッジとし，審美的 要素を十分に配慮した。唇側マージン部はポーセレンマ ージンとしカラーレスとした（図 5,6). 試啇時, 装着 時においても，ポンティック底の加圧に問題がないこと を確認し，ポーセレンマージン部はシランカップリング 処理を行い, レジンセメントにて接着した（図 7).ア ンテリアガイダンスも良好に機能し，偏心運動時に大臼 歯部が離開する咬合が確立し，審美面においても患者か 


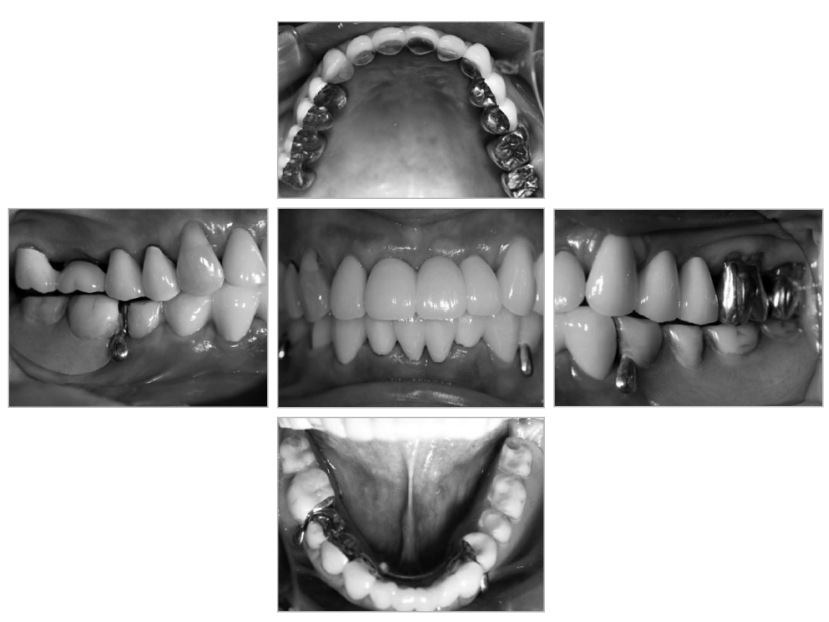

図 7 Intraoral view after final prosthetic treatment 最終補綴装置装着時口腔内写真

ら高い満足度が得られた。

術後 3 年 2 力月が経過し，上顎前歯欠損部，支台歯 隣接面の歯肉退縮もなく, 歯周組織の状態も落ち着いて おり大きなトラブルはなく経過している（図 8, 表 2).

\section{IV. 考 察}

本症例における前歯部補経装置脱離の問題点を整理す ると, 接着方法を含めた築造体の設計の不備, アンテリ アガイダンスの設定の不備，根管治療など，さまざまな 問題が考えられるが，本症例は Eichiner の分類におい て class B3 であり，臼歯部咬合支持の低下による上顎 前歯部への突き上げが最も大きな問題の 1 つであると 考えた。すなわち,

1. 下顎の可撤性部分床義歯の粘膜面の不適合による 義歯の沈下等により，特に垂直的な咬合支持が不 足していたこと

2. 11は，脱離を繰り返していくうちに，補綴装置が 浮き上がった状態で再装着されるなど，咬合の不 調和が生じていたことが推察されたこと

等, 補綴装置の装着後, 口腔内の変化に対応したメンテ ナンスが十分でなかったために，下顎前歯部による上顎 前歯部へ咬合圧が集中するようになり，特に，〈1の補綴 装置の脱離や歯根破折を生じさせた。

今回のように，抜歯予定歯の歯䅡ラインが両隣接歯よ り低位で, 歯根破折部位が歯冠側寄りで唇側の骨吸収が 少なかったことなどの条件が整えば，オベイトポンティ ックのプロビジョナルレストレーションを用いることで 歯槽骨の吸収防止, 歯肉縁形態, 歯間乳頭の維持をしな がら欠損部の形態変化に対応でき, 審美性を考慮した前 歯部補綴処置が可能なことがわかった。

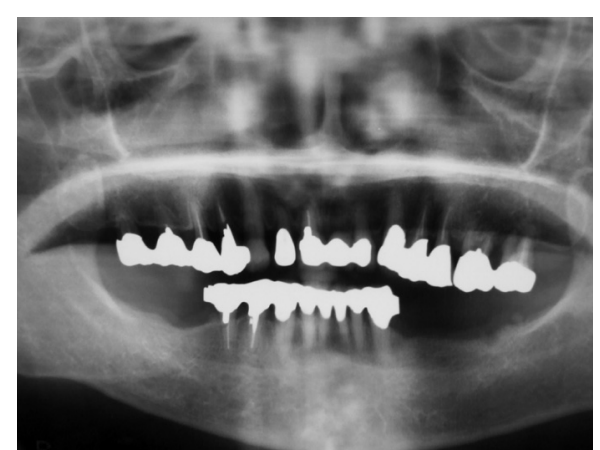

図 8 Orthopantomograph after final prosthetic treatment

最終補綴装置装着時パノラマX $\mathrm{X}$ 線写真

表 2 Periodontal conditions after final prosthetic treatment

最終補綴装着時歯周精密検査

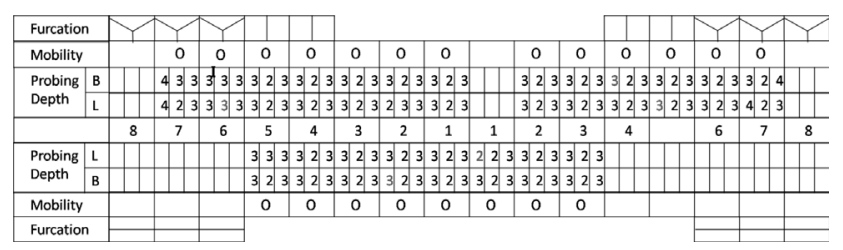

本症例では，咬合支持の低下による前歯部の歯根破折 が考えられたため, 今後パーシャルデンチャーの人工歯 の咬耗による咬合支持が低下しないように，また義歯床 内面の適合性の確認をしながら継続して予後管理を行つ ていく予定である.

\section{V. 結 論}

前歯部審美障害を訴える患者に対してオベイドポンテ イックを併用した固定性補綴装置を装着することで，患 者の満足を得ることができた。

\section{文献}

1) Turnow DP, Magner AW, Fletcher P. The effect of the distance from the contact point to the crest of bone on the presence or absence of the interproximal dental papilla. J Periodontal 1992; 63: 995-996

2）小濱忠一．前歯部審美修復天然歯編。難易度鑑別診断と その治療戦略，東京：クインテッセンス出版，2007, 190-216.

著者連絡先 : 一瀬 昭太

干221-0072 神奈川県横浜市西区浅間町 1-1-7

TEL: 045-311-3422

FAX: 045-311-3472

E-mail: shota19760428@yahoo.co.jp 